\title{
Potential Effects of
}

Trade Liberalization

on China's Imports of

Plastics From the GCC

Philipp Galkin, Carlo Andrea Bollino and Rami Shabaneh 


\section{About KAPSARC}

The King Abdullah Petroleum Studies and Research Center (KAPSARC) is a non-profit global institution dedicated to independent research into energy economics, policy, technology and the environment, across all types of energy. KAPSARC's mandate is to advance the understanding of energy challenges and opportunities facing the world today and tomorrow, through unbiased, independent, and high-caliber research for the benefit of society. KAPSARC is located in Riyadh, Saudi Arabia.

\section{Legal Notice}

(C) Copyright 2018 King Abdullah Petroleum Studies and Research Center (KAPSARC). No portion of this document may be reproduced or utilized without the proper attribution to KAPSARC. 


\section{Key Points}

etrochemical products, particularly plastics, contribute to a significant share of expanding and increasingly diverse trade flows between the Gulf Cooperation Council (GCC) countries and China.

The petrochemical sector could benefit from a preferential bilateral trade regime between China and the GCC, but has been a bone of contention in the GCC-China Free Trade Agreement (FTA) negotiation process. This study applies a dual-stage model of import demand functions to estimate the impact of trade liberalization scenarios, within an FTA framework, on China's imports of major plastics from the GCC and the rest of the world. It assesses the implications of these scenarios for all parties. We find that:

The elimination of import duties would lead to incremental annual sales from the GCC to China of $\$ 410$ million, based on 2016 data.

A zero-tariff regime would also result in net welfare gains for China and a \$242 million benefit to Chinese consumers from the trade creation effect.

Non-tariff barriers do not present a significant impediment to the competitiveness of imports on the Chinese plastics market.

The estimated effects of trade liberalization vary significantly across the products (tariff lines).

Polyethylene imports from the GCC to China could rise by over 11 percent, while polypropylene imports from the region would increase by 6.5 percent due to a more competitive domestic market. Thus, the distribution of potential export gains between GCC members depends on their capacity and export structure.

The impact of the GCC-China FTA on bilateral trade in plastics is likely to diminish in the medium- to long-term due to China's rapid build-up of new petrochemical capacities, and the development of economic ties with other producing countries. 


\section{Summary for Policymakers}

B ilateral trade between the Gulf Cooperation Council (GCC) countries and China has been expanding rapidly since the turn of the century. In 2016, China accounted for 12 percent of the GCC's imports, making it the largest exporter to the region. The GCC countries also heavily rely on China as one of their major export markets.

Still dominated by energy fuels, their exports to China are becoming increasingly diversified as the GCC producers strive to convert parts of their vast petroleum reserves into higher value-added products. In particular, plastics currently amount to about 7 percent of total GCC exports to China, or 30 percent of non-energy exports.

Developing trade and investment ties between the GCC and China called for institutional arrangements beyond the World Trade Organization (WTO) framework to further enhance economic cooperation. The GCC-China Free Trade Agreement (FTA) negotiations started in 2004 and, after several years of suspension, resumed in 2015. One of the major stumbling blocks in the negotiation process has reportedly been the issue of liberalizing petrochemical trade. Protecting its domestic producers, China proved to be reluctant to set forth significant concessions on import duties. Conversely, the GCC countries sought a preferential trade regime since the development of their petrochemical industries has been primarily driven by exports, with China representing a major global demand destination.

Understanding the potential effect that various liberalization scenarios for the petrochemicals trade can have on the major stakeholders may help to facilitate progress toward finalizing the FTA negotiations. This study aims to assess such effects through the following steps:
Estimating the impact of tariff reduction and the elimination of non-tariff barriers on the bilateral trade flows of three major plastics, classified according to the six-digit harmonized system (HS) 2012 code:

- 390110 - polyethylene with a specific gravity of less than 0.94 (including low-density polyethylene (LDPE) and linear low-density polyethylene (LLDPE) - together referred to as LDPES);

- 390120 - high-density polyethylene (HDPE) (a specific gravity of 0.94 or more).

- 390210 - polypropylene (PP).

Assessing the consequences for the parties involved:

- Opportunities for the GCC exporters (as a block and by country).

- Net welfare gains for China and the impact on its consumers and domestic producers.

Evaluating the feasibility of trade liberalization scenarios based on market developments and the estimated impact on key stakeholders.

This study develops and estimates a dual stage model of import demand functions and applies it to selected petrochemical products, to quantify the trade creation and trade diversion effects that occur as a consequence of trade liberalization. It first models total petrochemical imports into China. Second, it models import flows among competing exporters: the GCC and the rest of the world. This design allows for an estimation of import demand and import substitution price elasticities, and a simulation of alternative tariff reduction scenarios. 
We find that the price sensitivities and the structural composition of total Chinese imports differ significantly across products. The coefficients for import demand elasticity, which drives the trade creation effect, range from -0.29 for PP to -1.19 for HDPE. The dispersion of import substitution elasticities, which define trade diversion, is less pronounced with the smallest coefficient of -0.86 recorded for PP and the largest (-1.41) for LDPES.

Consequently, the reduction or elimination of Chinese import duties would potentially have a significant positive impact for plastics exporters in the GCC and its member countries. The analysis in this paper suggests that Saudi Arabia and the United Arab Emirates (UAE) would be best positioned to take advantage of such a scenario. These countries would be able to capture most of the gains in PP and HDPE segments, and Qatar could substantially increase its LDPES exports to China. This study estimates that if China dropped its import tariffs to zero, the annual increase in imports for the three major plastics would be $\$ 193$ million from Saudi Arabia, followed by $\$ 134$ million for UAE, \$54 million for Qatar and \$28 million for Kuwait, based on average 2016 import prices.

Reducing import tariffs would impact Chinese domestic producers through a trade creation effect: More efficient (cheaper) imports would partially replace less efficient (more expensive) domestic production. Domestic HDPE production seems to be most vulnerable to foreign competition. A zero percent tariff rate on GCC imports would result in a 3.2 percent increase in total HDPE imports, compared to a 1.3 percent increase for LDPES and a 0.5 percent increase for PP. On the other hand, liberalizing imports would allow Chinese consumers to benefit from reduced tariffs - estimated at \$256 million per annum - and create a $\$ 6.3$ million net welfare gain for the country.
Thus, the simulation results suggest that China's domestic plastics producers are the only major stakeholders who could potentially be disadvantaged by a preferential trade regime with the GCC. China's modest tariff concessions on petrochemicals imports granted to its existing FTA partners indicate that policymakers take their position into consideration. Reciprocal elimination of the GCC's import tariffs on Chinese products made from primary plastics (HS codes 3920 3926) could add balance to the bilateral trade flows within the petrochemical value chain. An FTA framework can also accommodate provisions that facilitate Chinese investment and joint projects with GCC counterparts in China or in the GCC region. This could help alleviate negative consequences for the domestic industry.

The import tariff levels for the products in this study represent a major impediment to competition and should be a priority in FTA negotiations. Distortions created by non-tariff barriers are estimated to be insignificant or negligible. Should the parties agree on trade liberalization terms, the estimated gains from increased bilateral trade appear feasible, given the current state of the global petrochemical market and the supply-demand dynamics of plastics in the GCC and China. China's demand for $P E$ and PP remains strong and reliant on imports, and the GCC countries are capable of increasing their exports to China. However, the window of opportunity for the GCC to expand its presence in the Chinese plastics market may be closing in the medium- to long-term. This is due to potential competition from increasing capacity build up in the United States, China's developing partnerships with existing and potential producers under the Belt and Road Initiative, and its drive for self-sufficiency. 


\section{The role of petrochemicals in GCC-China trade and FTA negotiations}

The rapid growth of Asian economies and their increasing need for energy access has attracted the interest of many resource-rich nations, particularly the Gulf Cooperation Council (GCC) member countries. While the GCC already plays a major role in energy diplomacy in key Asian countries, the relationship could be further enhanced using other policy tools such as free trade agreements (FTAs) that could provide a stimulus for trade and investments (Huyuh and Nakamura 2016). The GCC has initiated a number of FTAs with major Asian economies. So far, the GCC has only finalized an FTA with Singapore, while deals with other countries, including China, Japan and South Korea, are still under negotiation.

The growing economic role of China in the GCC region has influenced the drive to advance the cooperation policy agenda. On a value basis, China has surpassed the United States (U.S.) as the largest exporter to the GCC, representing over 12 percent (over $\$ 51$ billion) of total imports to the region in 2016 (World Bank 2017). GCC countries also see China as a large export market and a key demand center for energy products and other exports, as the former strive for diversification. Besides being a major energy supplier, the GCC is a key region for China's Belt and Road Initiative. Given their strong economic mutual interest and increasing economic ties, an FTA agreement could potentially present a number of mutually beneficial solutions for both parties.

FTA negotiations between China and the GCC started in 2004. However, the talks were suspended in 2009 after five rounds of negotiations. The former Chinese Minister of
Commerce, Gao Hucheng, indicated that both parties had reached a consensus on 97 percent of commodities, but those talks were put on hold due to the global financial crisis (Xinhuanet 2016). One of the major obstacles of the negotiation process was the issue of liberalizing the petrochemicals trade. China intended to protect its domestic industry and, consequently, was reluctant to reduce its import tariffs on petrochemical goods (Huyuh and Nakamura 2016; Puig and Yee 2017).

From the GCC's perspective, the elimination or reduction of import duties remains a crucial factor in the potential FTA deal with China. Developing the GCC's largely export-driven petrochemical industry will help to convert vast petroleum reserves into higher value-added products, reinforcing the region's economic and foreign trade diversification. A preferential trade regime with China would also give the GCC an edge over other major competitors for the Chinese market, such as the U.S.

petrochemical industry, revived on the back of the shale gas revolution. Projected incremental U.S. exports are assumed to be dominated by two of the most commonly used plastics: polyethylene (PE) and polypropylene (PP) (Doyle 2017), which accounted for some 30 percent of total non-energy imports to China from the GCC in 2016.

The two parties revived the FTA negotiations at the end of 2015 and have tried to reach a timely conclusion by accelerating talks. The parties have completed nine rounds of negotiations as of writing, and are making progress toward finalizing the deal.

\section{China: Developing domestic capacities but still reliant on imports}

China has dramatically expanded its petrochemical base on the strength of the rising manufacturing 
sector and demand for consumer goods. Its petrochemical capacity grew by sixfold between 2000 and 2014, representing 64 percent of the global capacity growth during this period (GPCA 2015). This capacity increase was dominated by ethylene plants, which subsequently led China to become a major producer of plastics. Between 2008 and 2015, China added 25.4 million tons of plastic production capacity and became the world's largest plastics producer, accounting for one-third of global production (GPCA 2017). The goal to increase its self-sufficiency, in order to accommodate broader targets of energy security, job creation and industrial value-addition (ICIS 2017), drives further capacity build up. This goal also drives the development of unconventional plastic producing routes such as coal-to-olefins, methanol-to-olefins and propane dehydrogenation (PDH).

Despite these efforts, China remains a large importer of key plastics, including PE and PP, and is likely to remain in this role for the medium term. Figure 1 shows that despite the increase in capacity, imports cover 40 percent of China's

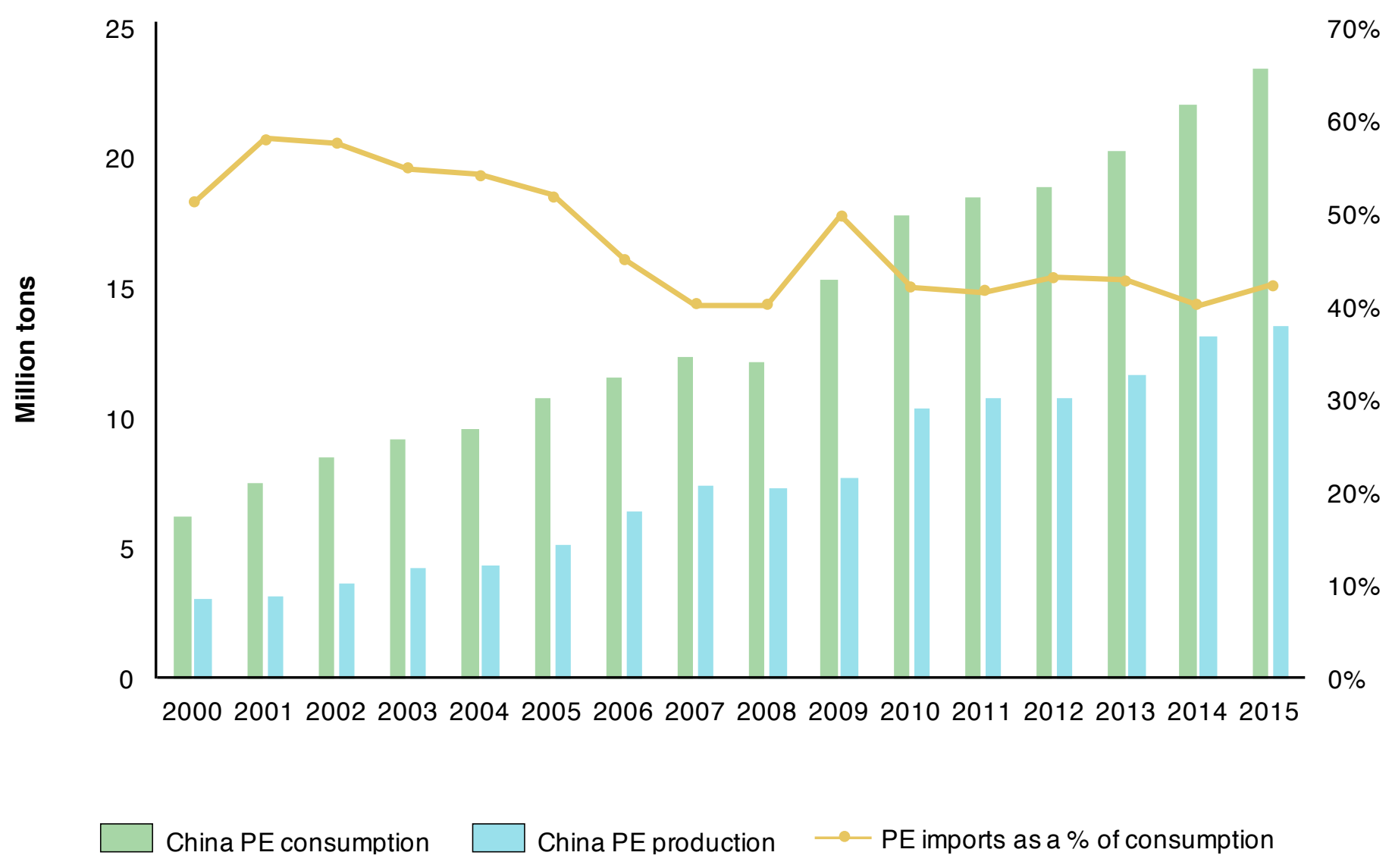

Figure 1. China's PE consumption, production and imports.

Source: KAPSARC; NEXANT, Bloomberg. 
PE demand. Meanwhile, foreign suppliers meet 20 percent of China's PP demand (see Figure 2). These products demonstrate different trends in recent years. The PE imports ratio has stabilized due to the lack of competitive domestic feedstock supplies (i.e., low-cost ethylene in the U.S. or subsidized feedstock in the GCC), while the share of imports in China's PP consumption has been steadily declining. A flurry of PDH unit installations has resulted in increased on-purpose propylene output supporting production growth in PP and a narrowing of the supply gap.

In an effort to reduce its reliance on imports, China tends to protect its domestic producers via import duties. Although significantly reduced since the accession to the WTO, its most favored nation (MFN) import tariffs for PE and PP amounted to 6.5 percent in 2016, compared to 14.2 and 10 percent respectively in 2002. Exporters of plastics to China have barely been able to take advantage of the preferential trade arrangements. Out of the top 10 exporters of PE to China in 2016, only Thailand, Malaysia and South Korea had an FTA with China. Imports of PE from South Korea are liable for a 6 percent preferential duty rate, while the rate for Malaysia and Thailand is the same as under the MFN treatment. Better trade terms have been given to PP importers who have an FTA with China. Korea and Association of Southeast Asian Nations (ASEAN)

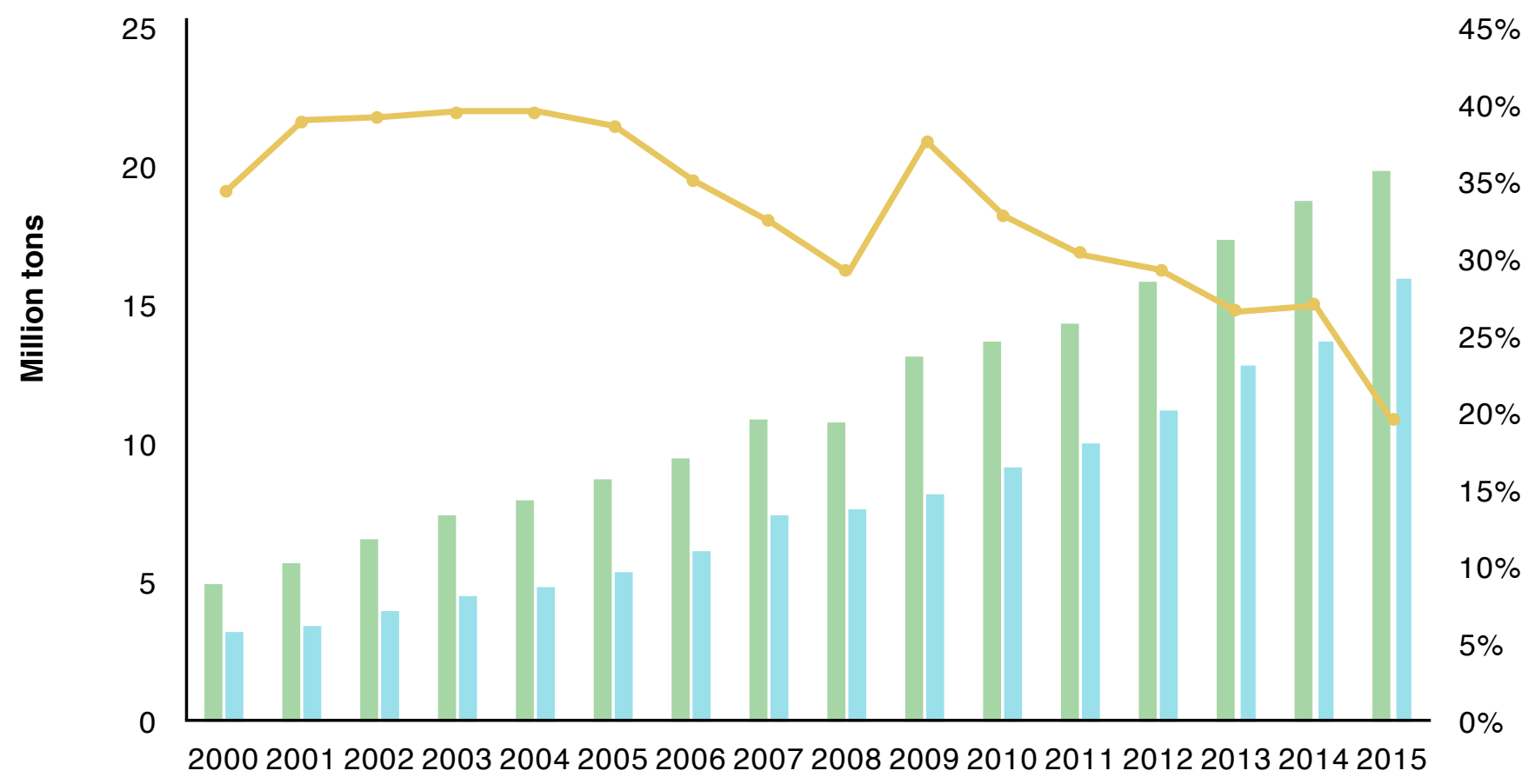

China PP consumption China PP production PP imports as a \% of consumption

Figure 2. China's PP consumption, production and imports.

Source: KAPSARC; NEXANT, Bloomberg. 
countries, who accounted for 50 percent of all PP imports into China in 2016, are eligible for a zero import tariff. Table 1 shows the current preferential tariff regimes for key exporters of plastics.

\section{GCC: A key exporter of plastics with high potential for growth}

The polymers sector, largely dominated by plastics production, is one of the fastest growing industries in the GCC. Between 2006 and 2016 it had a compound annual growth rate (CAGR) of 11 percent. Polymers generated almost $\$ 28$ billion of revenue in 2016, representing 36 percent of all chemical sales in the GCC during that year (GPCA 2017). This sector also contributes significantly to job creation, employing 40,000 people directly and 118,000 indirectly (GPCA 2017).

The Kingdom of Saudi Arabia (KSA) leads the GCC region as the largest polymer producer, representing two-thirds of its total production, followed by the UAE (18 percent), Qatar (8 percent), Kuwait (4 percent) and Oman (3 percent). Bahrain does not currently have

Table 1. Imports, shares and preferential tariff rates for China's FTA partners, as of 2016.

\begin{tabular}{|c|c|c|c|c|c|c|c|c|c|}
\hline \multirow[b]{2}{*}{$\begin{array}{l}\text { Import } \\
\text { source }\end{array}$} & \multicolumn{3}{|c|}{ LDPES (HS code 390110 ) } & \multicolumn{3}{|c|}{ HDPE (HS code 390120 ) } & \multicolumn{3}{|c|}{ PP (HS code 390210) } \\
\hline & $\begin{array}{l}2016 \\
\text { imports, } \\
\text { th. } \$\end{array}$ & $\begin{array}{l}\% \text { of } \\
\text { total } \\
\text { imports }\end{array}$ & $\begin{array}{l}\text { Preferential } \\
\text { tariff rate, \% }\end{array}$ & $\begin{array}{l}2016 \\
\text { imports, } \\
\text { th. } \$\end{array}$ & $\begin{array}{l}\% \text { of } \\
\text { total } \\
\text { imports }\end{array}$ & $\begin{array}{l}\text { Preferential } \\
\text { tariff rate, \% }\end{array}$ & $\begin{array}{l}2016 \\
\text { imports, } \\
\text { th. } \$\end{array}$ & $\begin{array}{l}\% \text { of } \\
\text { total } \\
\text { imports }\end{array}$ & $\begin{array}{l}\text { Preferential } \\
\text { tariff rate, \% }\end{array}$ \\
\hline Australia & 10,821 & $0.4 \%$ & $3.9 \%$ & 16,596 & $0.3 \%$ & $3.9 \%$ & 5,775 & $0.2 \%$ & $3.9 \%$ \\
\hline $\begin{array}{l}\text { Hong Kong, } \\
\text { China }\end{array}$ & 2,526 & $0.1 \%$ & $0 \%$ & 2,285 & $0 \%$ & $0 \%$ & 4,463 & $0.2 \%$ & $0 \%$ \\
\hline Indonesia & & & & 8,696 & $0.1 \%$ & $6.5 \%$ & 3,416 & $0.1 \%$ & $0 \%$ \\
\hline Korea, Rep. & 276,161 & $11 \%$ & $6 \%$ & 653,004 & $10.9 \%$ & $6 \%$ & $1,021,180$ & $40.6 \%$ & $0 \%$ \\
\hline Malaysia & 156,831 & $6.2 \%$ & $6.5 \%$ & 37,604 & $0.6 \%$ & $6.5 \%$ & 43,681 & $1.7 \%$ & $0 \%$ \\
\hline Philippines & & & & 6,876 & $0.1 \%$ & $6.5 \%$ & 1,448 & $0.1 \%$ & $0 \%$ \\
\hline Singapore & 94,227 & $3.7 \%$ & $6.5 \%$ & 44,661 & $0.7 \%$ & $6.5 \%$ & 416,406 & $16.6 \%$ & $0 \%$ \\
\hline Switzerland & 1,279 & $0.1 \%$ & $4.7 \%$ & & & & & & \\
\hline Thailand & 109,461 & $4.4 \%$ & $6.5 \%$ & 346,492 & $5.8 \%$ & $6.5 \%$ & 177,087 & $7 \%$ & $0 \%$ \\
\hline Vietnam & & & & & & & 37,000 & $1.5 \%$ & $0 \%$ \\
\hline
\end{tabular}

Source: UN Comtrade, World Bank. 
any polymer production capacity. PE and PP account for most of the GCC polymer industry. Figure 3 shows that the main polyolefins, including high-density polyethylene (HDPE), low-linear density polyethylene (LLDPE), low-density polyethylene (LDPE) and PP make up more than 85 percent of the GCC's total polymer production capacity.

The GCC's modest domestic demand has allowed it to establish itself as one of the world's largest exporter of plastics, despite having only 9 percent of the global plastics production capacity (27.1 million tons). On average, plastics exports make up about 7 percent of the region's non-oil trade on a value basis. For the KSA, Qatar and Kuwait the contribution is more significant, at 33 percent, 28 percent and 14 percent respectively. The regional export composition within the petrochemical sector has recently shifted away from basic chemicals toward polymers, taking advantage of the higher added value created in this segment.

About 60 percent of plastics exported from the GCC in 2016 went to Asia. On a country level, China is the primary importer of GCC plastics and accounts for a quarter of all GCC plastics exports. Figure 4 shows the breakdown for exports of major plastics (LDPES, HDPE and PP) from GCC countries.
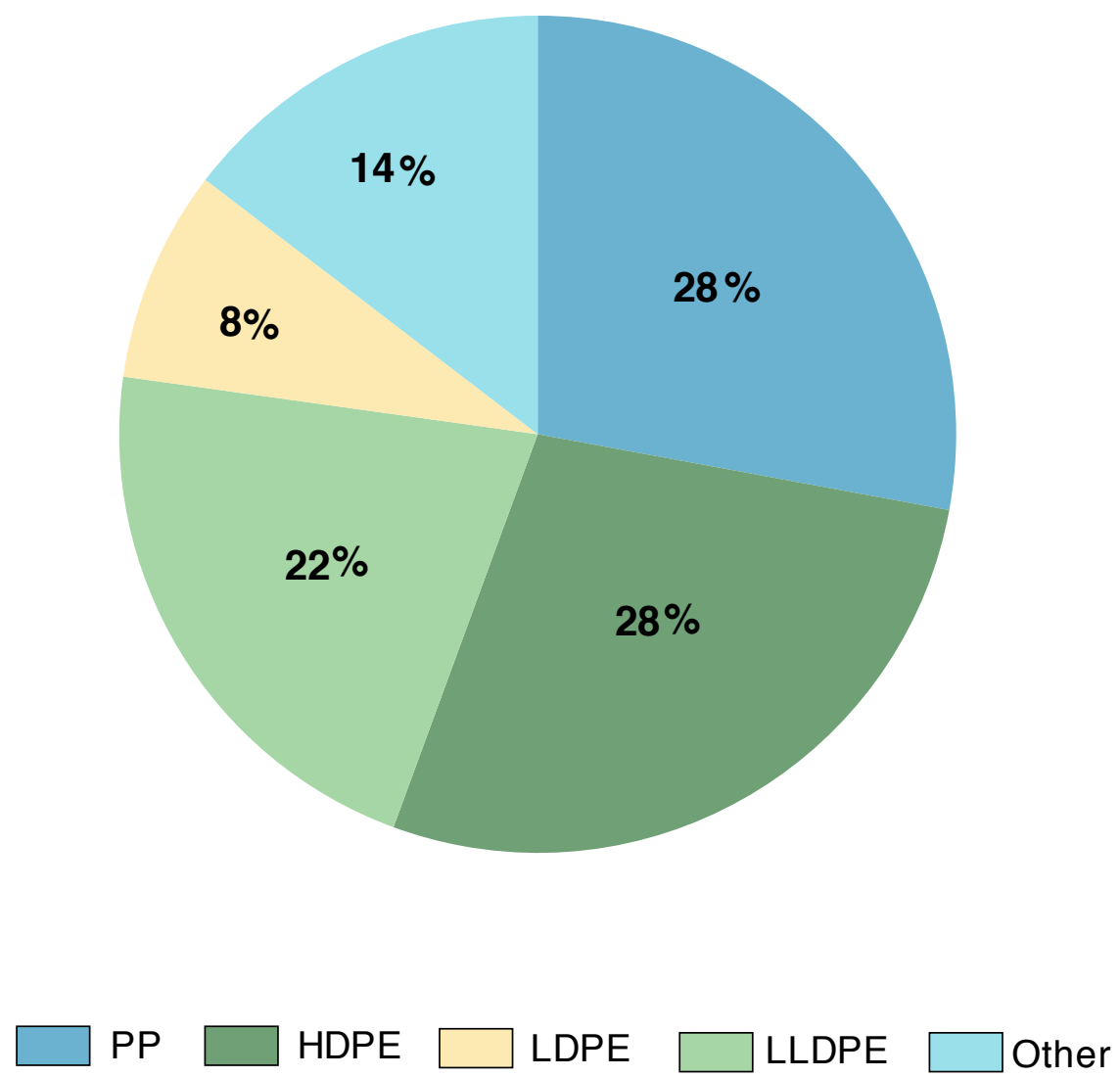

Figure 3. GCC polymer production capacity by product, 2016.

Source: GPCA. 


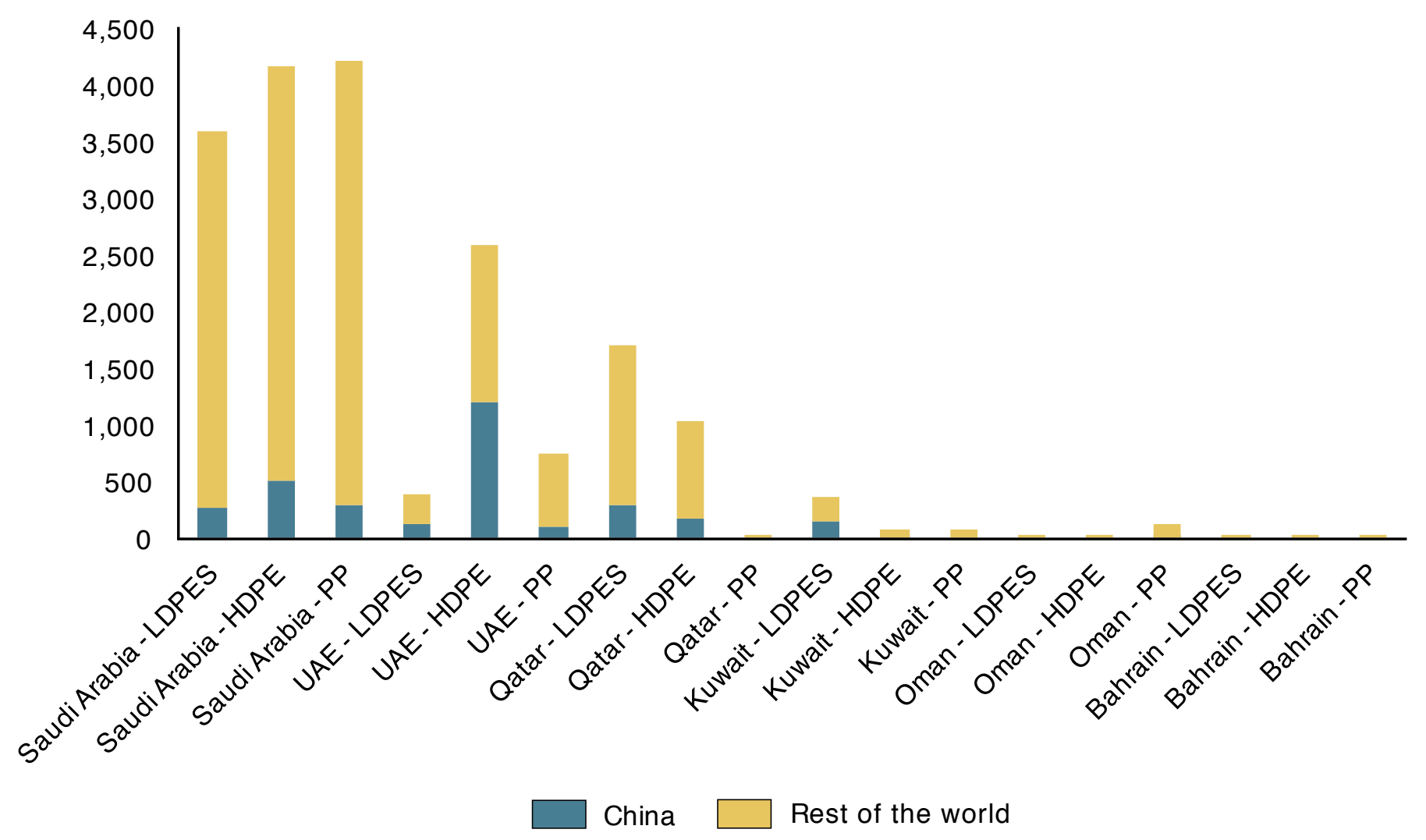

Figure 4. Export values of LDPES, HDPE and PP by destination in 2016, (\$ million).

Source: UN Comtrade.

The GCC will continue to fulfill China's growing need for plastics, even though China has announced capacity expansions within the short- and mediumterm (ICIS 2017). A potential FTA between China and the GCC could benefit the bilateral trade in petrochemical products, among other trade and investment flows. The ensuing sections of the paper evaluate the potential consequences of introducing a preferential trade regime for a group of key plastics products for both parties. 


\section{Scope, Method and Data}

\section{The scope of the study}

This study analyzes Chinese imports of three petrochemical/polymer product groups:

Polyethylene with a specific gravity of less than 0.94 (Harmonized System (HS) 2012 code 390110). This includes LDPE and LLDPE, aggregated as LDPES.

Polyethylene with a specific gravity of 0.94 or more (HS 2012 code 390120) (HDPE).

Polypropylene (HS 2012 code 390210) (PP).

GCC imports to China are differentiated from the rest of the world (RoW) for each product group.

The monthly data used to estimate import demand covers the period 2002-2016. The annual import substitution data covers the period 1996-2016.

\section{Methodology}

The study sets up and estimates a dual stage model of import demand functions at the disaggregated level of products - the 6-digit level of the HS 2012 classification. The first stage models the total import quantities of a given country. The second stage models the allocation of import flows among competing exporting countries.

Following the existing literature, import demand is derived from a standard optimization framework (Bussiere et al. 2013; Giansoldati and Gregori 2017; Soderbery 2015; Gözgör 2014; Fukumoto 2012; Kee, Nicita and Olarreaga 2008). In this framework, imports are driven by activity variables and price variables.

The general model applied to the problem is represented by:

$$
\begin{aligned}
& Y=F(X, Z, \varepsilon) \\
& Y_{i}=F\left(Y, X i, Z, \varepsilon_{i}\right)
\end{aligned}
$$

In the first stage, $\mathrm{Y}$ is the relevant import variable representing total Chinese imports, $F($.$) is the$ functional form, $\mathrm{X}$ is the set of activity variables which

\section{Impact of the exchange rate volatility}

Existing literature shows that exchange rate volatility represents expectations and uncertainty, and can be an additional influence on import demand and import prices. It can also demonstrate opposite effects, such as deterring trade flows because of risk aversion, or boosting trade to capitalize on higher volumes against the potential decrease in future revenue due to exchange rate volatility (Kim 2017; Kiliç 2016; Choudhry and Hassan 2015; Bahmani-Oskooee and Hegerty 2007).

There is evidence that the exchange rate structural effect on trade elasticities is weakening (Leigh et al. 2017) following the globalization of commodity markets. This study controls for the short term effect of exchange rate volatility, which may depend on importing firms' risk aversion. We find moderate evidence that higher risk aversion may hamper trade with high exchange rate volatility partners, implying a negative impact of $Z$ in equations (1) and (2). 
drive imports - representing domestic demand and relative prices of domestic and imported products and $Z$ is a variable representing the exchange rate volatility.

In the second stage, $Y_{i}$ is the relevant import variable representing trade flows from the GCC to China, $F($.) is the functional form, $Y$ is total imports, $X_{i}$ captures a competitive substitution effect through relative prices between imported products from the GCC and the rest of the world, and $Z$ is a variable representing the exchange rate volatility.

Note that in equations (1) and (2), the functional form $F($.$) is generally non-linear according to the theoretical$ specification. For instance, it is a constant elasticity of substitution (CES) in the Bergstrand, Egger and Larch (2013) model. For the study's estimation, equations (1) and (2) are linearized under the assumption of a Taylor approximation of the original function and are represented as follows:

$$
\begin{gathered}
\mathrm{Y}=\mathrm{Z} * \beta+\mathrm{X} * \alpha+\varepsilon \\
\mathrm{Yi}=\mathrm{Y} * \gamma+\mathrm{Z} * \beta+\mathrm{X}_{\mathrm{i}} * \alpha+\varepsilon
\end{gathered}
$$

Operationally, Y represents the dependent variables: the values and volumes of the three products' (HDPE, LDPE and PP) import flows. The estimation is carried out using two separate regressions for equations: (3), monthly data, and (4), annual data. The simulation model is constructed with both equations running at the annual level.

In this simulation model, the change in the relative price of imports from the GCC feeds into both the $X$ and $X_{i}$ variable matrix. It determines a general effect on total imports $Y$ via a weighted effect on the total import price contained in the $X$ variable matrix and a specific substitution effect via the relative import price contained in the $X_{i}$ variable matrix. Appendix 1 presents a detailed description of the econometric estimation procedure and characteristics of the model output.

This study assumes an infinite export supply elasticity, implying that exporters (in this case, the GCC countries) behave as price takers.

\section{Data and sources}

China's total monthly import volumes and values are sourced from the China Petroleum and Chemical Industry Federation (CEIC 2017). Annual imports by exporting destination are provided by the UN Comtrade database, accessed via the World Bank's World Integrated Trade Solution (WITS) online platform (World Bank 2017).

Historical and current tariff rates applied to Chinese imports, including the MFN, preferential and applied tariffs, are obtained from the United Nations Conference on Trade and Development's Trade Analysis Information System (TRAINS) and World Trade Organization's tariff database, also accessed via WITS (World Bank 2017).

China's domestic production and prices of LDPES, HDPE and PP are provided by the National Bureau of Statistics of China (CEIC 2017).

Average monthly and annual exchange rates of Chinese Yuan to the U.S. dollar are sourced from OANDA (OANDA 2017). 


\section{Modeling Results and Discussion}

\section{Import elasticities}

This study applies equations (3) and (4) to estimate import demand and import substitution elasticities in relation to price for the selected petrochemical products in focus. Table 2 presents the estimation results.

Import demand elasticity (IDE) represents a change in total import quantities that results from a change in the price of imported goods. The model output suggests that for every 1 percent price decrease, the total quantity of LDPES imported by China would increase by 0.74 percent. The increment would be higher for HDPE at 1.19 percent. These numbers fall within a range of elasticities estimated by scholars for the chemical industry (Ghodsi, Grübler and Stehrer 2016; Jahangir and Li 2007). However, the IDE value of Chinese PP imports indicates that import demand for this product is relatively inelastic to price. The impact of a potential tariff reduction on total Chinese imports for the GCC exporters would further vary depending on each product's share of the Chinese market.

Import substitution elasticity (ISE), in this formulation, quantifies the change in volume of products China imported from the GCC relative to the change in their prices compared with imports from other countries. The estimated ISE for HDPE and $P P$ is below 1, implying that if prices of GCC products targeting the Chinese market were to decrease by 1 percent, Chinese imports of HDPE and PP from the GCC would increase by 0.71 percent and 0.86 percent respectively. The GCC's gain would be at the expense of other exporters to China. These estimates indicate that HDPE and PP imports from the GCC and other countries are imperfect substitutes, due to differences in product specifications, long-term contract arrangements, and established supply chains, among other factors. Imports of LDPES, with an ISE of 1.41, are more elastic than imports of the other products. Note that estimated ISEs for all products in this study are lower than those suggested by default (1.5) in the World Bank's SMART model (World Bank 2017).

\section{Potential impact on trade}

This study uses the price elasticities derived from the import demand and import substitution equations (Table 2) to estimate the potential effect of a tariff reduction on import volumes. For this simulation, every other variable of equations (3)

Table 2. Estimated price elasticities of individual products.

\begin{tabular}{|c|c|c|c|}
\hline HS code & Product name & $\begin{array}{l}\text { Import demand elasticity } \\
\text { (China) }\end{array}$ & $\begin{array}{l}\text { Import substitution elasticity } \\
\text { (GCC vs. RoW) }\end{array}$ \\
\hline
\end{tabular}

\begin{tabular}{l|l|l|l}
390110 & $\begin{array}{l}\text { Polyethylene with a specific gravity } \\
\text { under 0.94 (LDPES) }\end{array}$ & -0.74 & -1.41 \\
\hline 390120 & $\begin{array}{l}\text { Polyethylene with a specific gravity of } \\
0.94 \text { or more (HDPE) }\end{array}$ & -1.19 & -0.71 \\
\hline 390210 & Polypropylene in primary forms (PP) & -0.29 & -0.86
\end{tabular}

Source: KAPSARC research. 
and (4) (income/demand and exchange rates) are constant. The study also assumes an infinite export supply elasticity, implying that the exporters of petrochemical products to China are not able to exercise their market power and behave as price takers. The simulation includes five tariff reduction scenarios, with each of the five equal steps representing a 20 percent reduction from the current 6.5 percent applied tariff level. Table 3 shows the potential increases in China's total imports, and imports from the GCC countries derived from the modeling scenarios.

The increase in total imports mostly occurs due to the trade creation effect: When Chinese domestic consumption shifts from higher cost (less efficient) producers protected by the import tariff barriers, to lower cost (more efficient) international producers. Conversely, the trade diversion effect largely drives increases in imports from GCC countries. In this case, consumption from more efficient international producers, who face a standard MFN tariff rate of 6.5 percent or a slightly lower FTA rate, is displaced by less efficient producers who benefit from better terms of trade under a preferential tariff regime.
Should China reduce import duties for the GCC, countries likely to experience significant trade diversion in petrochemical exports to China may include Iran, South Korea, the U.S. and ASEAN countries for PE exports, and Korea Japan and India for PP exports.

Chinese domestic HDPE production seems to be the most vulnerable sector to the potential impact of tariff liberalization. Chinese producers could lose 3.2 percent of the market to imports should the tariff rates for GCC exporters drop to zero. Domestic PP producers seem more competitive and would yield only a 0.5 percent market share under the fully liberalized import regime. The highest potential gains for GCC exporters from tariff elimination would be in the PE market segment, where the LPDES and HDPE market shares are expected to increase by 11.1 and 11.6 percent respectively. Potential gains in PP exports could also be substantial, at 6.4 percent under a zero-tariff assumption. Unlike PE, tariff concessions for this market are likely to face less opposition from the Chinese side, due to its relatively insignificant impact on the domestic industry.

Table 3. Increase in trade flows under tariff reduction scenarios (\%).

HS code Product name Trade flow Increase in trade under preferential tariff rates

\begin{tabular}{|c|c|c|c|c|c|c|c|}
\hline & & & $5.2 \%$ & $3.9 \%$ & $2.6 \%$ & $1.3 \%$ & $0 \%$ \\
\hline \multirow[t]{2}{*}{390110} & \multirow{2}{*}{$\begin{array}{l}\text { Low density } \\
\text { polyethylene }\end{array}$} & Total imports & 0.2 & 0.5 & 0.7 & 1.0 & 1.3 \\
\hline & & GCC imports & 2.1 & 4.2 & 6.4 & 8.7 & 11.1 \\
\hline \multirow[t]{2}{*}{390120} & \multirow{2}{*}{$\begin{array}{l}\text { High density } \\
\text { polyethylene }\end{array}$} & Total imports & 0.6 & 1.3 & 1.9 & 2.5 & 3.2 \\
\hline & & GCC imports & 2.2 & 4.4 & 6.8 & 9.2 & 11.6 \\
\hline \multirow[t]{2}{*}{390210} & \multirow{2}{*}{$\begin{array}{l}\text { Polypropylene in } \\
\text { primary forms }\end{array}$} & Total imports & 0.1 & 0.2 & 0.3 & 0.4 & 0.5 \\
\hline & & GCC imports & 1.2 & 2.5 & 3.8 & 5.1 & 6.4 \\
\hline
\end{tabular}

Source: KAPSARC research. 


\section{Non-tariff barriers: Do they matter?}

Besides tariff reduction, an FTA can also include specific clauses that reduce or eliminate nontariff barriers to trade (NTBs). NTBs arise from a domestic regulatory environment and market structure. Their mechanisms may include quotas, licensing, discriminatory product specification requirements, complicated customs procedures, subsidies to domestic producers and currency manipulation. Eliminating such barriers can further stimulate trade creation. However, quantitatively estimating the magnitude of the effects of each NTB can be a complicated task.

One approach to this problem is to apply a gravitybased model to estimate how NTBs impact trade flows when compared to potential trade flows without NTBs (Berden et al. 2009; Egger et al. 2015; Galkin, Bollino and Atalla 2017). Price-based approaches, on the other hand, compare prices in the importing country with the prices of similar goods undistorted by the NTBs (Ferrantino 2006; Dean et al. 2009). Resulting price differential can be used as an ad valorem measure for NTBs. Applying this method allows a comparison of the actual/observed values (prices), rather than actual and estimated values (trade flows) in the case of the gravity model approach.

Comparing domestic and import (cost insurance and freight $[\mathrm{CIF}]+$ average import tariff rate) prices for LDPES, HDPE and PP enables an estimation of the magnitude of NTBs facing exporters of PE and PP products to the Chinese market. Figure 5 shows the price comparison ratios.

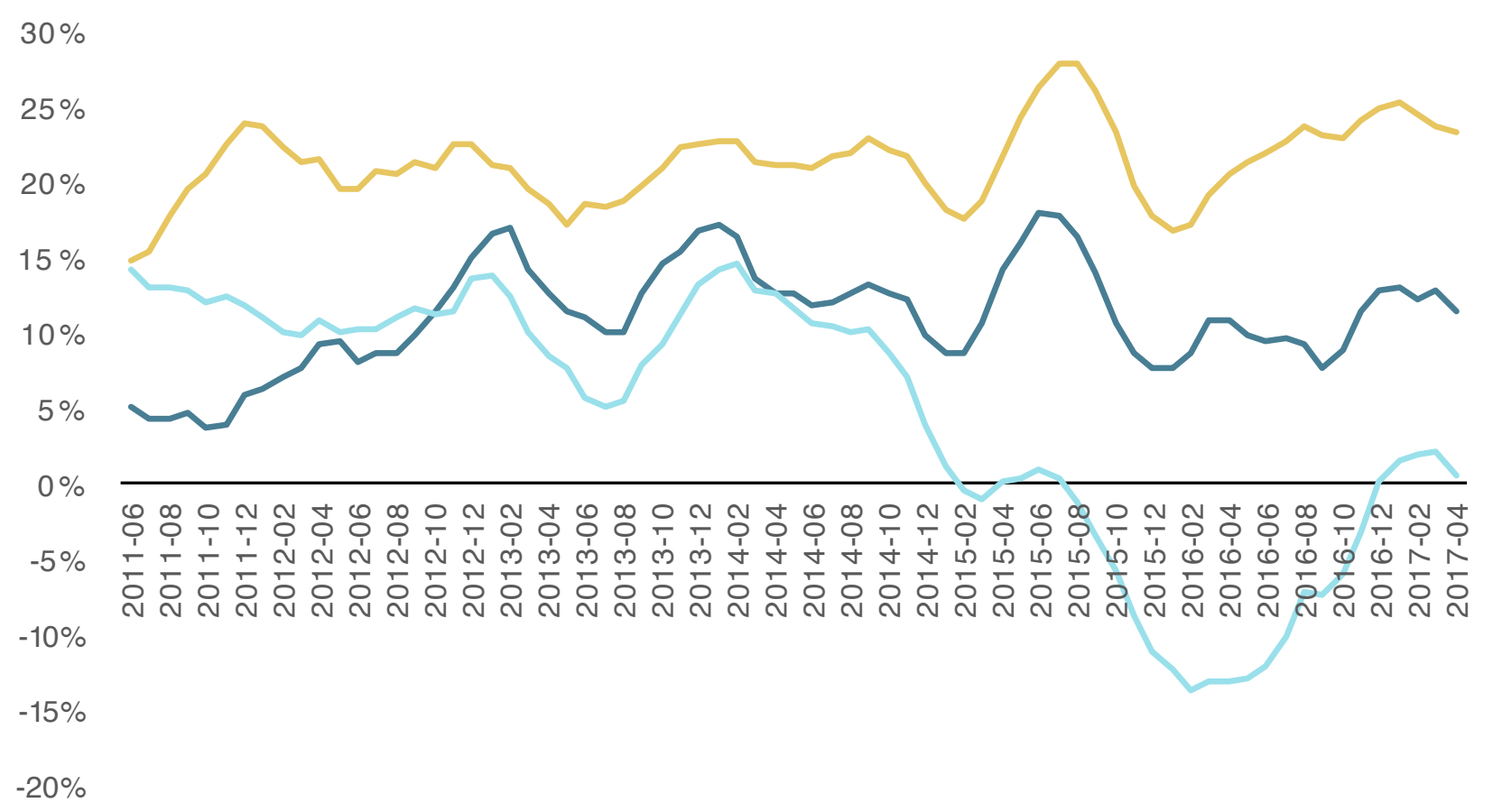

Ratio of domestic to average import prices (including tariffs), 6-month moving average

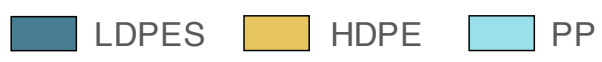

Figure 5. Comparison of domestic and imported prices for selected petrochemical products.

Source: World Bank, UN Comtrade, CEIC. 
HDPE products have the most significant price gap, within a 20-25 percent range. Considering that import prices do not include VAT at 17 percent and transportation costs from the customs location to consumers, we can assume that NTBs facing HDPE exporters to China have a minimal impact on prices, if any at all. The lower price differential level for LDPES - within a 10-15 percent range on average - signals that this product group's imports are not affected by NTBs, at least in the long run. The short-term fluctuations in price differentials, such as those observed in 2015 , reflect the time lag required for domestic Chinese prices to respond to global price shifts in petrochemicals and their inputs. The difference between domestic and import prices for PP is even smaller. The recent strong downward trend in the PP price differential signifies substantial efficiency improvements, increased competition in the domestic production sector and a negligible impact of non-tariff protectionist measures on the Chinese PP market.

This paper's conclusions, concerning the insignificant or negligible effects of NTBs facing exporters of PE and PP products on the Chinese market, are in line with the World Bank's estimations (World Bank 2017). The World Bank assigns a zero percent ad valorem equivalent to the NTBs for Chinese imports of LDPES, HDPE and PP product groups. As such, this study does not introduce additional scenarios that assess the impact of abolishing NTBs for PE and PP imports.

\section{Implications for China}

A potential reduction in Chinese import duties on $\mathrm{PE}$ and PP from GCC may cause an increase in total import volumes displacing less efficient domestic production. This scenario could lead, in turn, to consumer surplus and net welfare gains. Table 4 quantifies these effects.

The elimination of duties on pre-existing imports from the GCC transfers tariff revenues from the government to consumers. The amount transferred is estimated to be $\$ 256$ million in total for the three product groups. It is calculated as 2016 GCC import values multiplied by the 6.5 percent applied tariff. Redistributing lost tariff revenues from existing

Table 4. Effects of tariff reduction on China under the 'zero tariff' scenario (based on 2016 data).

$\begin{array}{llll}\text { HS code } & \text { Product name } & \begin{array}{l}\text { Trade creation } \\ \text { (\$ million) }\end{array} & \begin{array}{l}\text { Tariff revenues } \\ \text { transferred to }\end{array} \\ & & \text { consumers (\$ million) } & \text { (\$ million) }\end{array}$

\begin{tabular}{l|l|l|l|l|l}
390110 & $\begin{array}{l}\text { Low density polyethylene } \\
\text { (LDPES) }\end{array}$ & 32.7 & 44.7 & 0.6 \\
\hline 390120 & $\begin{array}{l}\text { High density polyethylene } \\
\text { (HDPE) }\end{array}$ & 191.9 & 157.0 & 5.4 \\
\hline 390210 & $\begin{array}{l}\text { Polypropylene in primary } \\
\text { forms (PP) }\end{array}$ & 17.6 & 54.3 & 0.3 \\
\hline Total: & & $\mathbf{2 4 2 . 2}$ & $\mathbf{2 5 6 . 0}$ & $\mathbf{6 . 3}$ &
\end{tabular}

Source: UN Comtrade, KAPSARC Research. 
imports does not generate gains for the country as a whole. However, the trade creation effect can lead to net welfare gains.

The trade creation effect is quantified as additional imported volumes at average prices in 2016. Based on the estimations in this study, China could expect a \$242.2 million increase in imports of PE and PP products under the 'GCC zero tariff' scenario. This would shift the supply cost curve for Chinese consumers, giving them access to cheaper products. China's net welfare gain is therefore estimated

\section{Conceptualizing the effect of eliminating tariffs on an importing country}

This partial equilibrium diagram illustrates the effects of import tariff elimination on national welfare and the shift in benefits for consumers and producers in the importing country.

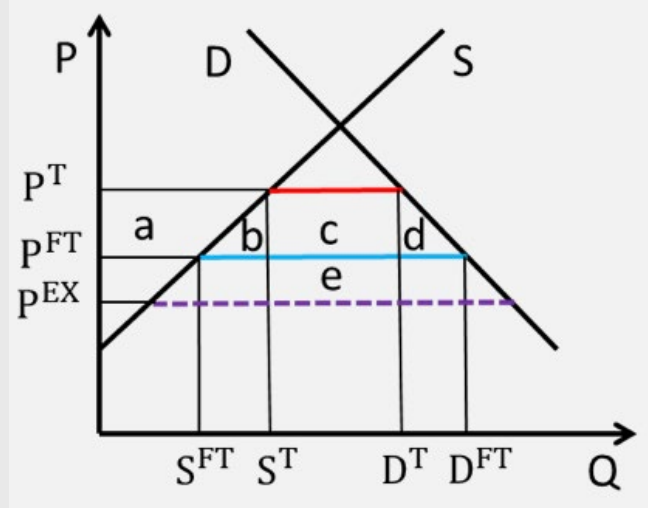

Removing the import tariff will reduce the domestic price $\mathrm{P}^{\top}$ to the level of the world equilibrium price $\mathrm{P}^{\mathrm{FT}}$ (assuming the absence of other trade barriers). As a result, increased imports will partially substitute less efficient domestic production. The blue line represents the quantity of new imports, and the red line represents imports under the tariff regime.

Domestic consumers will be better off due to decreased prices. Their surplus is represented by areas $(a)+(b)+(c)+(d)$.

Domestic producers, on the other hand, are negatively affected by decreased prices for their products. Reduction of consumer surplus is represented by area (-a).

The importing country's government loses the tariff revenue $(-c)$.

The importing country's net welfare is estimated as the sum of positive and negative effects for the producers, consumers and the government - the sum of areas (b) and (d) that denote production efficiency loss and consumption efficiency loss, due to market distortions caused by the tariff. If the importing country is large enough to impact the global equilibrium price (in which case exporters will reduce their price to $\mathrm{P}^{\mathrm{EX}}$ to partially compensate the price effect of the tariff), then removing the import tariff will also eliminate this country's positive terms of trade effect (-e). Thus, the net welfare effect will comprise of $(b)+(d)-(e)$. 
as the value of additional imports at pre-existing prices (including the pre-existing average tariff) minus their cost at a new supply price (assuming a new, reduced, average import tariff). The resulting increase in consumer surplus is estimated to be $\$ 6.3$ million.

Of the three product groups in this study, the HDPE sector has the potential to be the greatest contributor to China's consumer surplus and its net welfare gain. It also accounts for almost 80 percent of the trade creation effect. This suggests that there are significant opportunities for further optimization and efficiency increases in China's domestic HDPE production. Chinese LDPES and PP producers seem less vulnerable to competition from imports. Consequently, the effect of reducing import duties for these products would primarily manifest in the transfers of tariff revenues.

Chinese petrochemical producers would be the major disadvantaged party under this scenario. According to the estimations presented in Table 3, eliminating import tariffs for GCC exporters could result in a loss of market share by domestic producers of between $0.5-3.2$ percent, depending on the product. Given China's historical stance of protecting its domestic petrochemical industry in the FTA negotiations, it would be difficult to achieve an immediate steep tariff reduction. On the other hand, increased imports of petrochemicals will result in lower feedstock requirements, allowing reallocations of naphtha and liquefied petroleum gas to other sectors and reducing import dependency on these fuels. The latter would align with Chinese energy policy goals.

\section{Implications for GCC exporters}

A decrease or elimination of import duties by China could unlock significant benefits for the GCC's petrochemical sector. Exports from the Gulf region to China would become more competitive against other exporters and domestic Chinese producers. The GCC would thus benefit from both trade creation and trade diversion effects. Table 5 shows the potential export growth under the five tariff reduction scenarios.

Table 5. Potential increase in imports to China from the GCC (\$ million), based on 2016 prices.

HS code Product name Potential increase in imports from the GCC under preferential tariff rates

\begin{tabular}{l|l|l|l|l|l|l}
\hline \multicolumn{2}{c}{$5.2 \%$} & $3.9 \%$ & $2.6 \%$ & $1.3 \%$ & 74.3 \\
\hline 390110 & $\begin{array}{l}\text { Low density polyethylene } \\
\text { (LDPES) }\end{array}$ & 14.4 & 28.9 & 44.0 & 59.8 & 222.2 \\
\hline 390120 & $\begin{array}{l}\text { High densitypolyethylene } \\
\text { (HDPE) }\end{array}$ & 53.1 & 106.3 & 164.2 & 280.2 \\
\hline 390210 & $\begin{array}{l}\text { Polypropylene in primary } \\
\text { forms (PP) }\end{array}$ & 10.0 & 20.9 & 31.7 & 42.6 & 53.4 \\
\hline Total: & & $\mathbf{7 7 . 6}$ & $\mathbf{1 5 6 . 0}$ & $\mathbf{2 4 0 . 0}$ & $\mathbf{3 2 4 . 6}$ & $\mathbf{4 0 9 . 9}$
\end{tabular}

Source: UN Comtrade, KAPSARC Research. 
Prospective export gains could be significant, potentially increasing imports from the region by $\$ 409.9$ million under the 'zero tariff' scenario. HDPE exports have the highest potential impact on the Chinese market: contributing to more than 50 percent of the total gains for the three studied product groups. Consequently, the tariff concessions for PE and, especially, HDPE imports are likely to be a priority for the GCC countries in FTA negotiations.

The benefits of a preferential trade regime in petrochemicals with China are potentially substantial, though they would not be equally distributed among the GCC members. Table 6 details the potential gains in exports for each country, based on the pre-existing trade flows and shares of the bloc members' PE and PP products in the Chinese market in 2016.

According to the estimations detailed in Table 6, the main beneficiaries of liberalizing the petrochemicals trade with China would be Saudi Arabia and the UAE. As most of the gains come from HPDE, Saudi Arabia and the UAE will benefit from their strong position in this market in the import tariff reduction scenario. Saudi Arabia is also well positioned to take advantage of the potential increase in PP exports, while Qatar would benefit most from increased
LDPES exports. Bahrain, on the other hand, would barely have any gains from the preferential trade arrangements in PE and PP, while Oman would only enjoy marginal gains.

The highest relative increase in exports to China, as a share of total country's exports, would be observed for the petrochemical exports of Kuwait and the UAE, with 5.5 and 3.7 percent growth respectively. Other GCC members may also consider establishing a stronger presence in the Chinese market prior to prospective trade liberalization, to extract maximum value from preferential trade arrangements between China and the GCC.

The GCC petrochemical exporters differ not only in the structure of their industry exports, but also in price competitiveness, which is affected by the countries' policies administered feedstock prices. Administered feedstock prices may also contribute to varying effects of tariff removal on the increase in the bloc members' exports to China. Figure 6 shows the recent dynamics of CIF China prices (excluding import tariffs) for individual GCC producers compared with the average prices of other exporters (RoW).

Table 6. Distribution of potential gains among the GCC countries under the 'zero tariff' scenario, (\$ million), based on the 2016 market shares of Chinese imports.

GCC member country Trade increase by product (HS code classification) Total increase

\begin{tabular}{l|l|l|l|l} 
& $\mathbf{3 9 0 1 1 0}$ (LDPES) & $\mathbf{3 9 0 1 2 0}$ (HDPE) & $\mathbf{3 9 0 2 1 0}$ (PP) & \\
\hline Bahrain & - & - & - & - \\
\hline Kuwait & 0.1 & 28.3 & 0.0 & 28.4 \\
\hline Oman & - & - & 1.1 & 1.1 \\
\hline Qatar & 32.9 & 21.0 & - & 53.9 \\
\hline Saudi Arabia & 24.3 & 132.2 & 36.0 & 192.5 \\
\hline United Arab Emirates & 19.2 & 98.6 & 16.4 & 134.1
\end{tabular}

Source: UN Comtrade, KAPSARC research. 

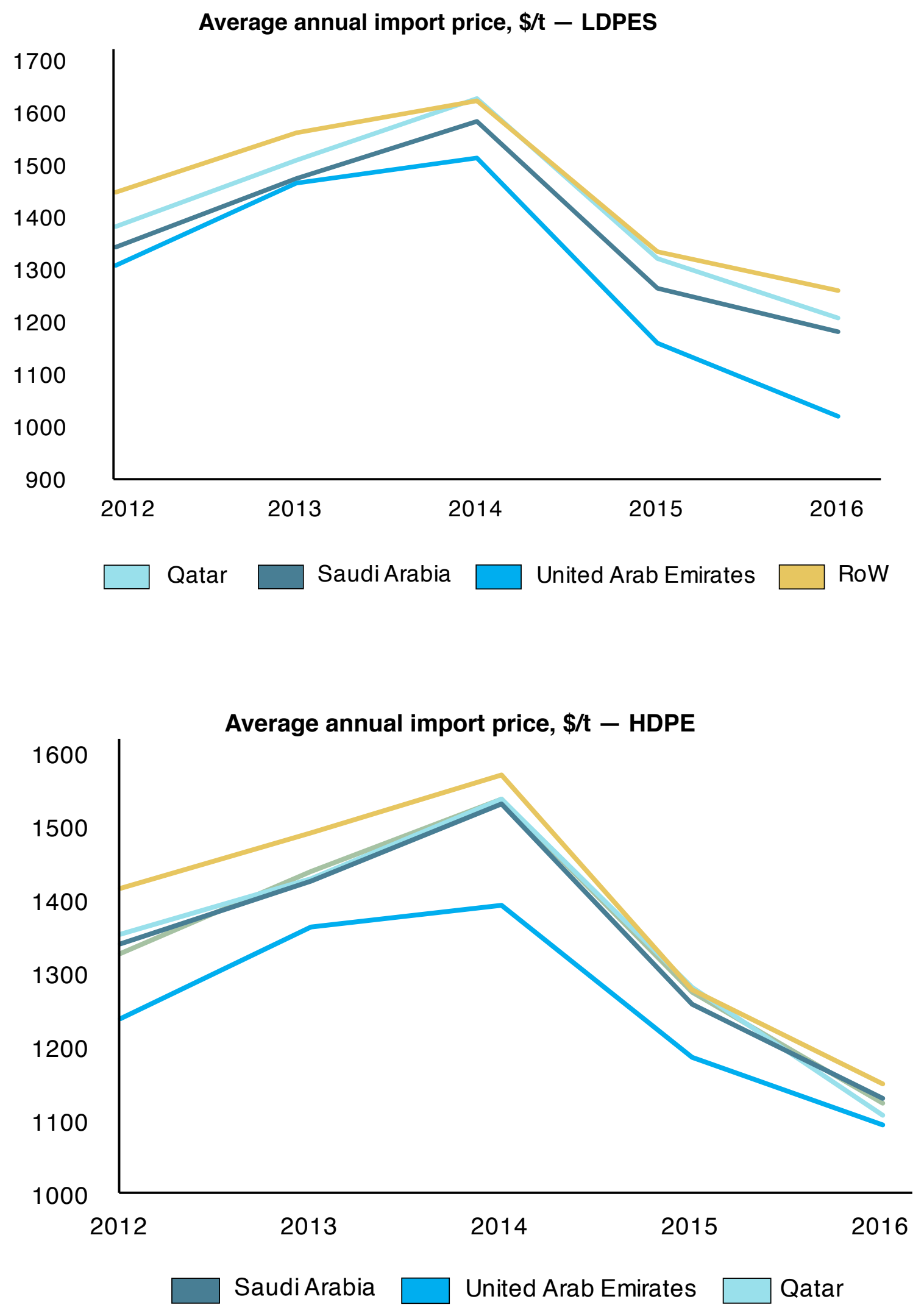

Kuwait

RoW 


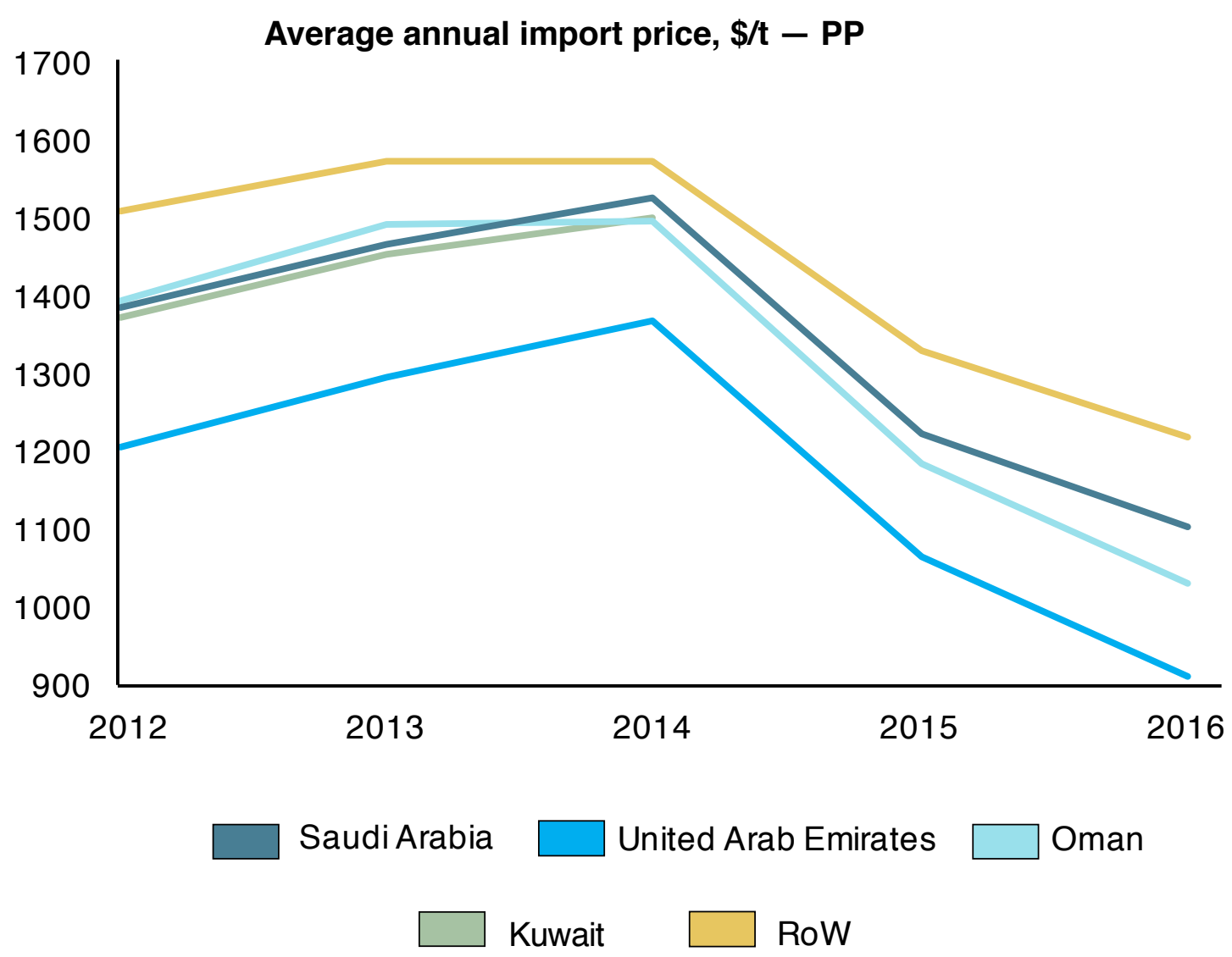

Figure 6. Average annual CIF prices of plastics imports to China (\$/t).

Source: UN Comtrade.

Each GCC country is already able to offer Chinese consumers lower prices for the product groups in focus than other foreign providers. The reduction or elimination of import duties could further increase this competitive advantage and result in substantial export gains, as this paper's analysis shows. Another way to utilize additional price margin obtained through preferential terms of trade with China is to 'internalize' it by increasing, or liberalizing, the domestic transfer prices of feedstock without inflicting significant damage to the margins of petrochemical producers. This would be in line with a number of reform initiatives undertaken in the GCC region.
Among GCC exporters, the UAE is the most price competitive in the Chinese market on average for all three product categories. The price dispersion among GCC exporters is relatively small for HDPE exports, whereas for PP and LDPES, Saudi Arabia, Qatar and Kuwait price their exports over 10 percent higher than the UAE. This price advantage can help the UAE increase its market share in China faster than its peers, should the import duties be reduced or dropped.

Polymer markets in the UAE, Kuwait and Qatar are dominated by single companies, each of which can take full advantage of a potential tariff reduction 
without having to consider competitive response in the domestic market. This position can also give them leverage in discussions with their respective governments on formulating feedstock pricing policies, keeping them competitive irrespective of tariff changes. The picture in Saudi Arabia is quite different. Despite SABIC and its affiliates owning the largest share of polymer production, there are a number of other polymer producers that may be impacted by changes in feedstock pricing. Thus, efficiency and cost competitiveness are key to growing market share and capitalizing on preferential trade terms.

\section{Feasibility of model estimations}

As this study's estimations demonstrate, a preferential tariff regime for imports of petrochemical products from the GCC countries to China would have a significantly positive impact on trade flows, bringing sizable benefits to both parties. However, for this scenario to materialize, several conditions have to be met:

Chinese imports of PE and PP do not reduce significantly in the short to medium term.

The GCC countries have enough existing or coming online capacity to increase exports, or can redirect their exports to China from other markets.

No major disruptions occur in the global petrochemical industry.

The parties sign an FTA within a reasonable time frame, and China makes tariff concessions for the PE and PP product groups.

According to the ICIS estimations, China will account for almost half of the global incremental petrochemical demand, or 30.6 million tons, until 2020 (ICIS 2016). ICIS also estimates that China will not reach self-sufficiency in PE until 2025, whereas in PP this goal can be achieved by 2020 (ICIS 2017). These dynamics explain the small trade creation effect and import demand elasticity observed for PP compared to HDPE and LDPES.

From the perspective of exporters' supply availability, the GCC countries plan to add 5.5 million tons of polymer production capacity, primarily in Saudi Arabia, Kuwait and Oman (GPCA 2017). Even if this capacity is delayed, it is reasonable to assume that GCC producers would be able to supply the estimated additional volumes to the Chinese market, as these volumes do not exceed 2.5 percent of the GCC's total exports in 2016.

Looking outside of China and the GCC, apart from potential global economic and political 'black swan' events, factors that may disrupt the current and projected supply-demand balance in the global petrochemical market are primarily on the supply side. These include substantial capacity build up in the U.S., accompanied by more affordable domestic feedstock and policy support, and Iran's plans to double its capacity by 2025 (Padjooh, Niakan and Taleifard 2017) to capitalize on its rich sources of feedstock in the post-sanctions environment.

The main focus for stakeholders in the petrochemical trade, when finalizing an FTA between the GCC and China, should be on liberalizing the tariff regime. Non-tariff clauses of a future FTA, such as those related to investments and customs procedures, can further facilitate trade relationships. As shown in previous sections, NTBs do not have a significant detrimental impact on PE and PP imports. 
Analysis of existing FTAs with China suggests it is reluctant to give significant concessions on import tariffs to its major petrochemical trading partners. As shown in Table 1, China did not reduce PE import duties for ASEAN countries. Though in recent FTA deals with key trade partners, China agreed to a moderate tariff decrease for South Korea and a progressive reduction schedule for Australia. Consequently, it is unlikely that the GCC countries would receive a zero PE import tariff in the first year the FTA comes into effect. However, given the importance of trade relationships between China and the GCC, certain Chinese concessions can be expected. The majority of significant PP exporters who have signed FTAs with China enjoy a zero-rate preferential tariff.

In sum, a fully liberalized petrochemical trade between the GCC and China within an FTA framework is unlikely to materialize in the shortterm. However, once an FTA is signed and enforced, the GCC should enjoy substantial gains. Even a moderate tariff reduction to 3.9 percent for PE products - the current level applied to Australian PE imports - and a likely 0 percent import tariff for PP could increase annual imports from the GCC by $\$ 189$ million. 


\section{Conclusions}

preferential tariff regime would have a significant impact on the petrochemical trade between the GCC and China. If China reduces its import tariffs for major plastics (polyethylene and polypropylene) to zero, the value of these products imported from the GCC countries could increase by $\$ 410$ million annually, based on 2016 data. HDPE (HS code 390120) has the potential to accrue over half of these gains due to the high sensitivity of its import volumes to price. Among the GCC members, the main beneficiaries of such a tariff regime would be Saudi Arabia and the UAE. Under the same tariff elimination scenario, Chinese consumers would also benefit from the trade creation effect (estimated at \$242 million), enabling them to purchase from more cost-efficient producers, as well as from the implicit transfer of tariff revenues from the government. A zero-tariff regime would also result in net welfare gains for China.

The current state of the global petrochemical market and the supply-demand dynamics of plastics in the GCC and China contribute to the feasibility of such a scenario. China's demand for $P E$ and PP remains strong and reliant on imports, and the GCC countries are capable of increasing their exports to China. However, the window of opportunity for the GCC to expand its presence in the Chinese plastics market may be closing in the medium- to long-term. This is due to the projected production capacity build up in the U.S., China's relentless drive to achieve self-sufficiency, and its developing partnerships with existing and potential producers under the Belt and Road Initiative.
The main impediment to liberalizing bilateral trade in plastics between China and the GCC lies in China's intention to protect its domestic producers: the only major stakeholder who could be disadvantaged by such an arrangement. China has revealed its position on this issue in granting modest tariff concessions to its existing FTA partners. China's protection of its domestic producers has been a bone of contention in previous negotiations with the GCC. A reciprocal elimination of the GCC's import tariffs on Chinese products made from primary plastics (i.e., those in the range of HS codes 39203926) could balance the bilateral trade flows within the petrochemical value chain. Chinese producers may also be interested in joint projects with their GCC counterparts or investing in petrochemical capacity in the GCC region, which could help alleviate their hostility to GCC competitors. An FTA could include provisions to facilitate this process.

Methodologically, the findings of this study suggest the need to estimate the effect of changes in terms of trade on a disaggregated level. Even within the same group, the behavior of import demand and import substitution functions, and the impact on domestic producers and importers, can vary significantly for each product or tariff line. The effect of eliminating non-tariff barriers, though proven insignificant in this study, also has to be taken into consideration for such analysis. Potential directions for further research may include introducing a finite foreign export supply elasticity (challenging the assumption of the price-taker behavior by exporters) and accounting for the product substitution effect in the target import market. 


\section{References}

Bahmani-Oskooee, Mohsen, and Scott William Hegerty. 2007. "Exchange rate volatility and trade flows: a review article." Journal of Economic Studies 3, 211-255. DOI: https://doi.org/10.1108/01443580710772777

Berden, Koen G., Joseph Francois, Martin Thelle, Paul Wymenga, and Saara Tamminen. 2009. NonTariff Measures in EU-U.S. Trade and Investment - An Economic Analysis. Reference OJ 2007/S180-219493, Ecorys report prepared for the European Commission.

Bergstrand, Jeffrey H., Peter Egger, and Mario Larch. 2013. "Gravity Redux: Estimation of gravity-equation coefficients, elasticities of substitution, and general equilibrium comparative statics under asymmetric bilateral trade costs." Journal of International Economics 89, 110-121.DOI: https://doi.org/10.1016/j. jinteco.2012.05.005

Bussiere, Matthieu, Giovanni Callegari, Fabio Ghironi, Giulia Sestieri, and Norihiko Yamano. 2013. "Estimating trade elasticities: Demand elasticities and the trade collapse of 2008-09." American Economic Journal: Macroeconomics 5 (3), 118-151. DOI: http://doi. org/10.3386/w17712

CEIC. 2017. China Economic \& Industry Data Database.

Choudhry, Taufiq, and Syed S. Hassan. 2015. "Exchange rate volatility and UK imports from developing countries: the effect of the global financial crisis." Journal of International Financial Markets, Institutions and Money 1-13. DOI: http://doi.org/10.1016/j.intfin.2015.07.004

Dean, Judith M., Robert Feinberg, Jose E. Signoret, Michael Ferrantino, and Rodney Ludema. 2009.

Estimating the Price Effects of Non-tariff Barriers. No. 2006-06-A(r), Washington, DC: U.S. International Trade Commission.

Doyle, Heather. 2017. "U.S. Petchem Sector Pushes Trump on NAFTA Plans." Petrochemical Update. November 3. http://analysis. petchem-update.com/supply-chain-logistics/ us-petchem-sector-pushes-trump-nafta-plans.

Egger, Peter, Joseph Francois, Miriam Manchin, and Douglas Nelson. 2015. "Non-tariff barriers, integration and the transatlantic economy." Economic Policy 30(83), 539-584. DOI: https://doi.org/10.1093/epolic/eiv008
Ferrantino, Michael J. 2006. Quantifying the Trade and Economic Effects of Non-Tariff Measures. OECD Trade Policy Papers, No. 28, Paris: OECD Publishing. DOI: http://dx.doi.org/10.1787/837654407568

Fukumoto, Mayumi. 2012. "Estimation of China's disaggregate import demand functions." China Economic Review 23(2), 434-444. DOI: http://doi.org/10.1016/j. chieco.2012.03.002

Galkin, Philipp, Carlo Andrea Bollino, and Tarek Atalla. 2017. The Effect of PTAs on Energy Trade from Chinese and Exporters' Perspectives. Riyadh: KAPSARC.

Ghodsi, Mahdi, Julia Grübler, and Robert Stehrer. 2016. Import Demand Elasticities Revisited. Working Paper 132, Wien: The Vienna Institute for International Economic Studies.

Giansoldati, Marco, and Tullio Gregori. 2017. "A note on the estimation of import trade demand functions." Economics Letters 157, 133-135. DOl: http://doi. org/10.1016/j.econlet.2017.06.012

Gözgör, Giray. 2014. "Aggregated and disaggregated import demand in China: An empirical study." Economic Modelling 43(C), 1-8. DOI: http://doi.org/10.1016/j. econmod.2014.07.033

GPCA. 2017. GCC Plastic Industry Indicators 2016. Dubai: Gulf Petrochemicals \& Chemicals Association.

GPCA. 2015. The GCC Chemical Industry Facts and Figures 2014. Dubai: GPCA.

Huyuh, Duc, and Yugo Nakamura. 2016. Energy Relations and Policy Making in Asia. Riydh: Palgrave Macmillan.

ICIS. 2017. China Moves Towards Commodity Grade PE Self-Sufficiency By 2025. May 22. http://www.icis.com/ blogs/asian-chemical-connections/2017/05/china-movestowards-commodity-grade-pe-self-sufficiency-by-2025/ 
-. 2017. "China To Now Raise Ethylene Capacity by $84 \%$ As Self-Sufficiency Drive Accelerates." ICIS. October 4. Accessed November 29, 2017. http://www.icis.com/ blogs/asian-chemical-connections/2017/10/china-to-nowraise-ethylene-capacity-by-84-as-self-sufficiency-drivesaccelerates/

ICIS. 2016. "Regional Scenarios in the Petrochemicals Markets."

Jahangir, Aziz, and Xiangming Li. 2007. China's Changing Trade Elasticities. International Monetary Fund.

Kee, Hiau Looi, Alessandro Nicita, and Marcelo Olarreaga. 2008. "Import demand elasticities and trade distortions." Review of Economics and Statistics 90(4), 666-682. DOI: https://doi.org/10.1162/rest.90.4.666

Kiliç, Rehim. 2016. "Regime-dependent exchange-rate pass-through to import prices." International Review of Economics \& Finance 41, 295-308. DOI: https://doi. org/10.1016/j.iref.2015.08.003

Kim, Chang Beom. 2017. "Does exchange rate volatility affect Korea's seaborne import volume?" The Asian Journal of Shipping and Logistics 33(1), 43-50. DOI: https://doi.org/10.1016/j.ajsl.2017.03.006

Leigh, D., W. Lian, M. Poplawski-Ribeiro, R. Szymanski, V. Tsyrennikov, and H. Yang. 2017. Exchange Rates and Trade: A Disconnect? IMF Working Paper, IMF.
OANDA. 2017. Average Exchange Rates.

Padjooh, Hamidreza Haghighat, Ali Niakan, and Atiyeh Taleifard. 2017. Iran seeks strategic development of its petrochemical industry. November 3. Accessed December 12, 2017. https://www.icis.com/subscriber/ icb/2017/11/03/10159694/iran-seeks-strategicdevelopment-of-its-petrochemical-industry/

Puig, Gonzalo Vialta and Alice Tung Ho Yee. 2017. "Challenges and opportunities of the China - Gulf Cooperation Council Free Trade Agreement." Hastings international and comparative law review 123-158.

Soderbery, Anson. 2015. "Estimating import supply and demand elasticities: Analysis and implications." Journal of International Economics 96, 1-17. DOI: 10.1016/j. jinteco.2015.01.003

Wood Mackenzie. 2015. "The Chemical State of Mind."

World Bank. 2017. Ad-Valorem Equivalents of Non-Tariff Barriers.

World Bank. 2017. World Integrated Trade Solution.

Xinhuanet. 2016. China, GCC vow to reach comprehensive FTA within 2016. January 20. Accessed November 26, 2017. http://news.xinhuanet.com/ english/2016-01/20/c 135028705.htm 


\section{Appendix 1. Econometric Estimation}

$\mathrm{T}$ Tis appendix provides a detailed description of the data used and of the econometric model estimation procedure. It uses data from several sources and with mixed frequency

Monthly data for the period February 2011-December 2016 produced 183 observations for the following variables:

Total monthly import volumes and values from the China Petroleum and Chemical Industry Federation (CEIC 2017).

The National Bureau of Statistics of China provided domestic production quantities and production prices of LDPES, HDPE and PP (CEIC 2017).

Average monthly exchange rates of Chinese Yuan to the U.S. dollar are sourced from OANDA (OANDA 2017).

Annual data for the period 2003-2016 produced a total of 14 observations for the following variables:

The UN Comtrade database provided imports by exporting destination (World Bank 2017).

Annual exchange rates were computed as averages of monthly data.

Historical and current tariff rates applied to Chinese imports, including the MFN, and preferential and applied tariffs, were obtained from the UNCTAD Trade Analysis Information System (TRAINS) and WTO Tariff database (World Bank 2017).

We estimate the model in two stages for each product, using the general form $Y=F(X, \varepsilon)$, where $Y$ is the dependent variable, $\mathrm{X}$ is a set of explanatory variables and $\varepsilon$ is an error term.

For the first stage (monthly frequency), the dependent variable $Y$ is the log of China's total imports. The explanatory variables are the log of domestic demand $D$, the log of the relative prices of imported products $\mathrm{PM}$ to domestic $\mathrm{PD}$ and a variable representing the exchange rate volatility $Z$.

For the second stage (annual frequency), the dependent variable $Y_{G}$ is the log of China's imports from the GCC. The explanatory variables are the log of China's total imports $Y$, the log of relative prices between imported products from the GCC $P_{G}$ and the rest of the world $\mathrm{P}_{w}$, capturing a competitive substitution effect and a variable representing the exchange rate volatility $Z$.

The general representation of the model is as follows:

$$
\mathrm{Y}=\alpha_{1}+\alpha_{2} \mathrm{P}_{\mathrm{M}} / \mathrm{P}_{\mathrm{D}}+\alpha_{3} \mathrm{D}++\alpha_{4} \mathrm{Z}+\varepsilon
$$

$$
\mathrm{Y}_{\mathrm{G}}=\beta_{1}+\beta_{2} \mathrm{P}_{\mathrm{G}} / \mathrm{P}_{\mathrm{w}}+\beta_{3} \mathrm{Y}+\beta_{4} \mathrm{Z}+\varepsilon
$$

Operationally, $Y$ represents the dependent variable for the three products HDPE, LDPES and PP. The estimation is carried using three separate regressions for equations (A1) for each product at the monthly frequency, and three separate regressions for equations (A2) for each product at the annual frequency. Then the variables of equation (A1) are aggregated at the annual frequency and a simulation model is constructed with equations (A1) and (A2) running at the annual level.

In this simulation model, the change in the relative price of imports from the GCC feeds into both the $X$ and $X_{i}$ variable matrix, determining a general effect on total imports $Y$ via a weighted effect on the total import price contained in the $\mathrm{X}$ variable matrix, and a specific substitution effect via the relative import price contained in the $\mathrm{X}_{i}$ variable matrix.

Table A1 gives the estimated parameters and the diagnostics for each equation for the first stage, and Table A2 gives them for the second stage. The 
estimated values appear to be plausible. The coefficients of all the equations are significant at 1 percent, with some at 5 percent levels. All the price elasticities are precisely determined and have plausible values, ranging from -0.3 to -1.4 . Note that the scale variable has an elasticity below one in the first stage and above one in the second stage.

Table A1. Estimation first stage.

\begin{tabular}{|c|c|c|c|}
\hline Dependent variables & Log LDPES & Log HDPE & Log PP \\
\hline \multicolumn{4}{|l|}{ Explanatory variables } \\
\hline $\begin{array}{l}\text { Constant } \\
\text { t- stat } \\
\text { P-value }\end{array}$ & $\begin{array}{l}1.81038 \\
2.99750 \\
{[.003]}\end{array}$ & $\begin{array}{l}4.05531 \\
3.28182 \\
{[.001}\end{array}$ & $\begin{array}{l}4.49834 \\
22.5175 \\
{[.000]}\end{array}$ \\
\hline $\begin{array}{l}\log _{\mathrm{P}_{M}} / \mathrm{P}_{\mathrm{D}} \\
\text { t- stat } \\
\mathrm{P} \text {-value }\end{array}$ & $\begin{array}{l}-1.19567 \\
-5.57131 \\
{[.000]}\end{array}$ & $\begin{array}{l}-.736881 \\
-2.51045 \\
{[.012]}\end{array}$ & $\begin{array}{l}-.292529 \\
-1.92670 \\
{[.054]}\end{array}$ \\
\hline $\begin{array}{l}\text { Log D } \\
\text { t- stat } \\
\text { P-value }\end{array}$ & $\begin{array}{l}.641565 \\
10.6370 \\
{[.000]}\end{array}$ & $\begin{array}{l}.191296 \\
2.53466 \\
{[.025]}\end{array}$ & $\begin{array}{l}.162511 \\
5.41089 \\
{[.000]}\end{array}$ \\
\hline $\begin{array}{l}\text { Z } \\
\text { t- stat } \\
\text { P-value }\end{array}$ & $\begin{array}{l}-.082293 \\
-2.37603 \\
{[.018]}\end{array}$ & $\begin{array}{l}-.078252 \\
-2.19330 \\
{[.033]}\end{array}$ & \\
\hline R square & .726 & .14 & .18 \\
\hline S.E. of regression & 58.8 & 116.7 & 52.0 \\
\hline $\log L$ & -1008.9 & -955.6 & -980.7 \\
\hline $\mathrm{N}$ of observations & 183 & 183 & 183 \\
\hline
\end{tabular}

Source: KAPSARC research.

Table A2. Estimation second stage.

\begin{tabular}{|c|c|c|c|}
\hline Dependent variables & Log LDPES & Log HDPE & Log PP \\
\hline \multicolumn{4}{|l|}{ Explanatory variables } \\
\hline $\begin{array}{l}\text { Constant } \\
\text { t- stat } \\
\text { P-value }\end{array}$ & $\begin{array}{l}-3.84700 \\
-1.96268 \\
{[.050]}\end{array}$ & $\begin{array}{l}-3.50904 \\
-.800051 \\
{[.424]}\end{array}$ & $\begin{array}{l}-10.1411 \\
-6.26881 \\
{[.000]}\end{array}$ \\
\hline $\begin{array}{l}\log P_{G} / P_{w} \\
\text { t- stat } \\
P \text {-value }\end{array}$ & $\begin{array}{l}-1.41144 \\
-1.14355 \\
{[.253]}\end{array}$ & $\begin{array}{l}-.857099 \\
-2.34191 \\
{[.019]}\end{array}$ & $\begin{array}{l}-.707534 \\
-2.30966 \\
{[.021]}\end{array}$ \\
\hline $\begin{array}{l}\log Y \\
\text { t- stat } \\
\text { P-value }\end{array}$ & $\begin{array}{l}1.30099 \\
5.09936 \\
{[.000]}\end{array}$ & $\begin{array}{l}1.86708 \\
3.49601 \\
{[.000]}\end{array}$ & $\begin{array}{l}2.08551 \\
10.8504 \\
{[.000]}\end{array}$ \\
\hline $\begin{array}{l}\text { Z } \\
\text { t- stat } \\
\text { P-value }\end{array}$ & $\begin{array}{l}.475604 \\
1.98311 \\
{[.047]}\end{array}$ & $\begin{array}{l}-.783967 \\
-6.32236 \\
{[.000]}\end{array}$ & \\
\hline R squared & .946 & .936 & .949 \\
\hline S.E. of regression & 38.0 & 116.7 & 165.3 \\
\hline LM het. test & $.417307[.518]$ & $.76337[.316]$ & $.768184[.381]$ \\
\hline $\log L$ & -68.4 & -84.1 & -96.2 \\
\hline $\mathrm{N}$ of observations & 14 & 14 & 14 \\
\hline
\end{tabular}

Source: KAPSARC research. 


\section{Notes}




\section{About the Team}

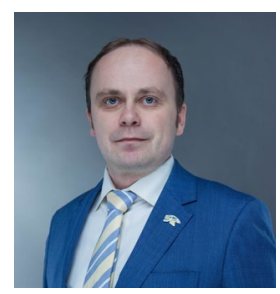

\section{Philipp Galkin}

Philipp is a research fellow specializing in the economic and policy aspects of energy supply and trade. He holds a Ph.D. in International Economic Relations and an MBA.

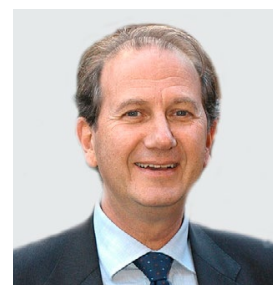

\section{Carlo Andrea Bollino}

Carlo is a visiting fellow at KAPSARC and professor of economics at the University of Perugia, Italy, specializing in microeconomic analysis, energy economics and environmental policy. He holds a Ph.D. in Economics from the University of Pennsylvania.

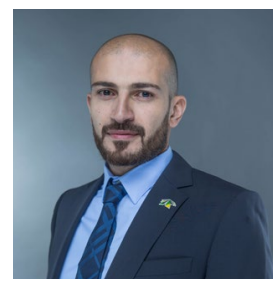

\section{Rami Shabaneh}

Rami is a research associate focusing on global gas and liquids markets. He has more than 10 years of research and industry experience in energy market analysis. He holds an M.Sc. in Sustainable Energy Development from the University of Calgary.

\section{About the Project}

The aim of the project is to assess the impact of tariff regimes and non-tariff policies of preferential trade agreements on the flows of energy products and investments of participating economies, their foreign trade structure and economic welfare. The project also intends to contribute to developing analytical frameworks that facilitate the estimation of these relationships. 
ANAPSARC

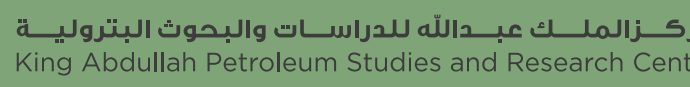

www.kapsarc.org 